\title{
HUBUNGAN PERAN PERAWAT DALAM RESPONSE TIME DENGAN TINGKAT KEPUASAN PELANGGAN DI IGD RUMAH SAKIT UMUM KABUPATEN TANGERANG
}

\author{
Ricka Ardila Susanti, Kusniawati \\ Politeknik Kesehatan Kemenkes Banten \\ Korespondensi: kusniawati@poltekkesbanten.ac.id
}

\begin{abstract}
Emergency unit as the first intra-hospital unit that is accessed by patients or families to get quick, precise and holistic initial help, especially in emergency cases. This condition requires priority handling of patients who come to the emergency room according to the response time (response time). The handling is carried out by officers according to their respective roles. The role of nurses that can be done include caregiver, client advocate, counselor, educator, collaborator, coordinator and consultant. Emergency events usually take place suddenly so it is difficult to predict the time of occurrence, it makes the government requires each hospital to meet the needs as the main strategy oriented to patient satisfaction. Objective To determine the relationship of the role of nurses in response time with the level of customer satisfaction in the emergency unit General Hospital, Tangerang Regency. Research Methods research design uses analytic study methods with approach cross sectional. The research sample was nurses who play a role in response time and patients and families. The analysis in this study used the test Chi-Square. The results showed a relationship between the role of nurses in response time with customer satisfaction, namely the $p$ value of $0.001(<\alpha 0.05)$. This confirms the role of nurses was very important in determining customer satisfaction. Conclusions It was expected that nurses can increase their role during response time in providing excellent service.
\end{abstract}

Keywords: nurse roles, response time, customer satisfaction

\begin{abstract}
ABSTRAK
Instalasi Gawat Darurat sebagai unit pertama intra rumah sakit yang diakses oleh pasien atau keluarga untuk mendapatkan pertolongan awal yang cepat,tepat dan holistik terutama pada kasus kegawatdaruratan. Kondisi ini membutuhkan prioritas penanganan pasien yang datang ke IGD sesuai waktu tanggap (response time). Penanganan tersebut dilakukan petugas sesuai peranannya masing-masing. Adapun peran perawat yang dapat dilakukan meliputi caregiver, client advocate, counsellor, educator, collaborator, coordinator dan counsultan. Kejadian gawat darurat biasanya berlangsung secara tiba-tiba sehingga sulit memprediksi waktu terjadinya, hal tersebut membuat pemerintah menuntut setiap rumah sakit untuk memenuhi kebutuhan sebagai strategi utama yang berorientasi pada kepuasan pasien. Tujuan penelitian untuk mengetahui hubungan peran perawat dalam response time dengan tingkat kepuasan pelanggan di IGD Rumah Sakit Umum Kabupaten Tangerang. Desain penelitian menggunakan metode studi analitik dengan pendekatan cross sectional. Sampel penelitian merupakan perawat yang berperan dalam response time dan pasien maupun keluarga. Analisis dalam penelitian ini menggunakan uji Chi-Square. Hasil Penelitian menunjukkan adanya hubungan antara peran perawat dalam response time dengan kepuasan pelanggan yakni nilai $p$ value $0,001(<\alpha 0,05)$. Hal tersebut menegaskan peran perawat sangat penting dalam menentukan kepuasan pelanggan.
\end{abstract}


Diharapkan perawat dapat meningkatkan peranannya selama response time dalam memberikan pelayanan prima.

\section{Kata Kunci : Peran perawat, response time, kepuasan pelanggan}

\section{PENDAHULUAN}

Rumah Sakit sebagai salah satu sub-sistem pelayanan kesehatan menyelenggarakan dua jenis pelayanan yaitu pelayanan kesehatan dan pelayanan administrasi. Pelayanan kesehatan meliputi pelayanan medik, penunjang medik, rehabilitasi medik, dan layanan perawatan (Muninjaya, 2013: 148). Pelayanan yang diberikan oleh Rumah Sakit dilaksanakan melalui beberapa unit yang ada di Rumah Sakit salah satunya Instalasi Gawat Darurat. Menurut Krisanty, dkk (2009:1) "pelayanan gawat darurat (emergency nursing) merupakan pelayanan keperawatan yang komprehensif diberikan kepada pasien dengan injury akut atau sakit yang mengancam kehidupan”.

Instalasi Gawat Darurat atau IGD sebagai unit pertama intra rumah sakit yang dapat diakses oleh pasien atau keluarga pasien untuk mendapatkan pertolongan awal yang cepat, tepat dan holistik terutama pada kasus kegawatdaruratan. "Berdasarkan data Direktorat Jenderal Bina Pelayanan Medik Depkes pada Tahun 2007, jumlah rumah sakit di Indonesia sebanyak 1.319 yang terdiri atas 1.033 RSU dengan jumlah kunjungan ke RSU sebanyak 33.094.000, sementara data kunjungan ke IGD sebanyak 4.402.2015 (13,3 \% dari total seluruh kunjungan di RSU), dari jumlah seluruh kunjungan IGD terdapat 12,0 \% berasal dari pasien rujukan. Jumlah yang signifikan ini kemudian memerlukan perhatian yang cukup besar dengan pelayanan pasien gawat darurat" (Keputusan Menteri Kesehatan RI, 2009).

Karakteristik pasien gawat darurat yang cepat mengancam nyawa meliputi henti napas dan henti jantung sehingga dalam waktu 6-8 menit menyebabkan pasien mengalami kematian klinis, setelah 8-10 menit tanpa denyut nadi, kerusakan ireversible terjadi pada otak (Yayasan Ambulans Gawat Darurat 118, 2015: 10). Karakteristik pasien IGD memiliki tingkat kegawatan yang berbeda - beda, sehingga dapat diklasifikasikan menjadi gawat darurat (emergency), gawat tetapi tidak darurat (urgent),tidak gawat dan tidak darurat (non emergency) dan meninggal. Kondisi ini membutuhkan adanya prioritas dalam penanganan pasien yang datang ke IGD sesuai dengan waktu tanggap (response time).

Penanganan setiap pasien yang datang memiliki response time yang berbeda - 
beda. Standar response time suatu rumah sakit disesuaikan dengan kebijakan rumah sakit atau mengikuti peraturan pemerintah. Berdasarkan Keputusan Kementerian Kesehatan RI nomor 856/Menkes/SK/IX/ 2009 menyatakan "pasien gawat darurat harus ditangani paling lama 5 (lima) menit setelah sampai di IGD”. Selain itu menurut Kartikawati (2012: 14) "skala triage Kanada menggambarkan response time pada pasien dengan kategori resusitasi yaitu langsung ditangani oleh dokter dan perawat, pasien kategori gawat darurat langsung ditangani oleh perawat dan $<15$ menit waktu untuk ditangani dokter, pasien kategori darurat waktu untuk ditangani dokter dan perawat $<30$ menit, sedangkan pasien kategori biasa waktu untuk ditangani dokter dan perawat $<60$ menit dan pasien kategori tidak gawat waktu untuk ditangani dokter dan perawat < 120 menit".

Dalam kondisi waktu tanggap (response time) petugas kesehatan terutama perawat dituntut untuk dapat segera memberikan penanganan yang cepat, tepat dan holistik. Penanganan tersebut dapat dilakukan secara mandiri maupun kolaborasi dengan petugas kesehatan lainnya atau sesuai dengan peranannya masing - masing. Adapun peran perawat yang dapat dilakukan meliputi care giver, client advocate, counsellor, educator, collaborator, coordinator dan counsultan.
Oleh karena itu, penanganan pasien sesuai prioritas dan adanya peran perawat dalam response time dapat menjadi bagian tolok ukur terhadap mutu pelayanan kesehatan yang selanjutnya memberikan umpan balik yaitu adanya kepuasan pelanggan.

Menurut Riskesdas (2013) kejadian gawat darurat biasanya berlangsung secara tiba - tiba sehingga sulit memprediksi waktu terjadinya, hal tersebut membuat pemerintah menuntut setiap rumah sakit untuk memenuhi kebutuhan sebagai strategi utama yang berorientasi pada kepuasan pasien. Kepuasan pasien merupakan perbedaan antara harapan pasien dengan kenyataan yang diterima (Priyoto, 2014: 246). Menurut Tomsal Siboro (2014) dalam Eko Widodo (2015), mengatakan "kepuasan pelanggan/ pasien ditentukan oleh keseluruhan pelayanan yaitu pelayanan admisi/ pendaftaran pasien, dokter, perawat, makanan, obat-obatan, sarana dan peralatan, fasilitas, dan lingkungan fisik rumah sakit serta pelayanan adiministrasi”. Penelitian di Amerika Serikat tentang tingkat kepuasan pasien di IGD menunjukkan bahwa dari 10 orang pasien yang berkunjung ke IGD diketahui 6 pasien (60 \%) mengeluh tentang pelayanan perawatan yang diberikan tidak sesuai dengan harapan dan 4 orang lainnya (4\%) mengatakan ketidakpuasannya mengenai 
fasilitas yang diberikan relatif lama dan memiliki proses yang rumit (Suryani, 2010) dalam Merry Gledis Sixten Gobel (2016). Suatu pelayanan kesehatan dapat memberikan kepuasan pelanggan terutama dalam kasus kegawatdaruratan, apabila perawat memiliki empati (sikap peduli) yang ditujukan oleh petugas kesehatan, responsiveness (kecepatan petugas menanggapai keluhan pasien), reliability (keandalan dan keterampilan) petugas kesehatan merawat pasien, assurance (jaminan keamanan yang ditunjukkan oleh petugas kesehatan) dan tangibility (kenyamanan ruangan) (Muninjaya, 2013: 169-170).

Peneliti telah melakukan studi pendahuluan yang dilakukan pada tanggal 27 Januari 2017 di IGD Rumah Sakit Umum Kabupaten Tangerang. Studi pendahuluan tersebut dilakukan dengan menanyakan langsung atau wawancara kepada kepala Ruangan. Hasil studi pendahuluan tersebut didapatkan bahwa IGD Rumah Sakit Umum Kabupaten Tangerang telah memiliki standar waktu pelayanan (response time) sesuai klasifikasi pasien (triage) untuk ditangani dokter yakni 0 menit untuk kategori pasien gawat darurat (merah), 30 menit untuk kategori pasien tidak gawat tetapi darurat (kuning) dan 60 menit untuk kategori pasien tidak gawat dan tidak darurat (hijau). Kepala Ruangan IGD juga menyampaikan telah ada penilaian kepuasan pelanggan di Rumah Sakit Umum Kabupaten Tangerang salah satunya di IGD, namun belum ada yang menghubungkan kepuasan pelanggan dengan peran perawat dalam response time. Oleh karena itu, peneliti tertarik untuk mengangkat judul penelitian "Hubungan Peran Perawat dalam Response Time dengan Tingkat Kepuasan Pelanggan Di IGD Rumah Sakit Umum Kabupaten Tangerang”.

Tujuan umum adanya penelitian ini untuk mengetahui hubungan antara peran perawat dalam response time dengan tingkat kepuasan pelanggan di IGD Rumah Sakit Umum Kabupaten Tangerang. Adapun tujuan khusus meliputi: mengindentifikasi peran perawat dalam response time di IGD Rumah Sakit Umum Kabupaten Tangerang, mengidentifikasi tingkat kepuasan pelanggan di IGD Rumah Sakit Umum Kabupaten Tangerang, menganalisis hubungan antara peran perawat dalam response time dengan tingkat kepuasan pelanggan di IGD Rumah Sakit Umum Kabupaten Tangerang.

\section{METODE}

Desain penelitian menggunakan metode studi analitik dengan pendekatan cross sectional. Penelitian ini dilakukan di IGD Rumah Sakit Umum Kabupaten Tangerang pada tahun 2017. Sampel penelitian 
merupakan perawat yang berperan dalam response time dan pasien maupun keluarga. Jumlah sampel dalam penelitian ini adalah 106 orang. Analisis dalam penelitian ini menggunakan uji Chi-Square.

\section{HASIL DAN PEMBAHASAN}

Hasil analisis univariat peran perawat dalam waktu tanggap (response time) dan tingkat kepuasan pelanggan dapat dilihat sebagai berikut:

\section{Tabel 1. Distribusi Frekuensi Responden}

\begin{tabular}{lcc}
\hline Variabel & $\begin{array}{c}\text { Frekuensi } \\
(\mathbf{n})\end{array}$ & $\begin{array}{c}\text { Prosentase } \\
(\mathbf{\%})\end{array}$ \\
\hline $\begin{array}{l}\text { Peran } \\
\text { Perawat }\end{array}$ & & \\
\hline Kurang & 15 & 14,2 \\
\hline Baik & 91 & 85,8 \\
\hline Total & $\mathbf{1 0 6}$ & $\mathbf{1 0 0}$ \\
\hline Kepuasan & & \\
Pelanggan & & \\
\hline Tidak Puas & 16 & 15,1 \\
\hline Puas & 90 & 84,9 \\
\hline Total & $\mathbf{1 0 6}$ & $\mathbf{1 0 0}$ \\
\hline
\end{tabular}

Berdasarkan hasil statistik pada tabel 1 dapat disimpulkan bahwa sebagian besar peran perawat di Instalasi Gawat Darurat Rumah Sakit Umum Kabupaten Tangerang dalam kategori baik sebanyak $91(85,8 \%)$ dan tingkat kepuasan pelanggan sebagian besar berada dalam kategori puas sebanyak 90 responden $(84,9 \%)$.

Pada analisis bivariat ini menggambarkan hasil analisis beserta uji statistik yang digunakan. Hasil uji statistik
Chi-Square dapat dilihat pada tabel berikut ini:

Tabel 2 Analisis Hubungan Peran Perawat Dalam Response Time Dengan Tingkat Kepuasan Pelanggan

\begin{tabular}{|c|c|c|c|c|c|c|c|}
\hline \multirow{3}{*}{$\begin{array}{c}\text { Peran } \\
\text { Perawat }\end{array}$} & \multicolumn{4}{|c|}{ Kepuasan Pelanggan } & \multirow{2}{*}{\multicolumn{2}{|c|}{ Total }} & \multirow{3}{*}{$\begin{array}{c}P \\
\text { value }\end{array}$} \\
\hline & \multicolumn{2}{|c|}{$\begin{array}{l}\text { Tidak } \\
\text { Puas }\end{array}$} & \multicolumn{2}{|c|}{ Puas } & & & \\
\hline & $\mathbf{N}$ & $\%$ & $\mathbf{N}$ & $\%$ & $\mathbf{N}$ & $\%$ & \\
\hline $\begin{array}{c}\text { Kurang } \\
\text { Baik }\end{array}$ & 7 & 46,7 & 8 & 53,3 & 15 & 15 & 0,001 \\
\hline Baik & 9 & 9,9 & 82 & 90,1 & 91 & 91 & \\
\hline
\end{tabular}

Berdasarkan hasil analisis tabel 2 menunjukan nilai $p$-value pada continuity correction $^{b}$ yaitu sebesar 0,001 karena $p$ value pada continuity correction ${ }^{b}<\alpha(0,05)$ pada taraf signifikan $5 \%$ artinya ada hubungan antara peran perawat dalam response time dengan tingkat kepuasan pelanggan di Instalasi Gawat Darurat Rumah Sakit Umum Kabupaten Tangerang.

Berdasarkan hasil penelitian menunjukkan bahwa sebagian besar peran perawat di Instalasi Gawat Darurat Rumah Sakit Umum Kabupaten Tangerang dalam kategori baik yaitu 91 (85,8\%). Peran perawat yang telah dilakukan oleh perawat di Instalasi Gawat Darurat Rumah Sakit Umum Kabupaten Tangerang sesuai yang diamati oleh peneliti meliputi care giver, 
client advocate, counsellor, educator, collaborator dan coordinator.

Menurut pendapat Iskandar (2013: 33) menyatakan bahwa peran perawat adalah seperangkat tingkah laku yang diharapkan oleh orang lain terhadap seseorang dalam suatu sistem. Doheny (1982) dalam Iskandar (2013: 33) juga menyatakan bahwa peran perawat terdiri dari care giver, client advocate, counsellor, educator, collaborator dan coordinator. Peran tersebut akan menggambarkan suatu tindakan keperawatan yang dilakukan sesuai perannya meliputi fungsi independent artinya perawat mandiri dan tidak bergantung pada orang lain dalam melaksanakan tindakannya dalam memenuhi kebutuhan dasar manusia seperti kebutuhan fisiologis (oksigenasi, cairan dan elektrolit, nutrisi, aktivitas, keamanan dan kenyamanan, cinta mencintai, harga diri dan aktualisasi diri), fungsi dependent artinya perawat dalam melakukan kegiatan atas instruksi perawat lain atau dokter, dan fungsi interdependent artinya fungsi saling ketergantungan antara tim satu dengan yang lainnya, fungsi ini dapat terjadi apabila membutuhkan kerja sama tim dalam memberikan pelayanan seperti memberikan asuhan keperawatan pada penderita yang mempunyai penyakit kompleks, sehingga kondisi seperti ini tidak hanya dapat diatasi oleh tim perawat tetapi juga dokter (Iskandar, 2013: 33).

Dalam hal ini, dapat dikatakan bahwa peran tersebut merupakan suatu bentuk kegiatan pelayanan dari petugas kesehatan dalam melayani pasien dimulai saat datang ke IGD hingga mendapatkan penanganan terutama oleh perawat.Pada kondisi di lapangan perawat telah melakukan perananannya di mulai daridaerah triagedengan melakukan pengkajian pada setiap pasien yang masuk ke IGD berdasarkan tingkat kegawatan dengan berfokus menemukan masalah pada airway (A), breathing (B), circulation (C), disability (D) dan exposure (E). Hal ini sesuai dengan Tim Bantuan Medis Panacea (2013: 29) menyatakan bahwa triase (triage) merupakan suatu prosedur yang menempatkan pasien pada kategori kategori prioritas untuk transpor dan perawatan berdasarkan tingkat keparahan cedera serta kegawatdaruratan medis, yang ditentukan dengan pertimbangan tata cara pertolongan menggunakan sistem ABC (Airway-BreathingCirculation) untuk di lapangan atau di rumah sakit".

Pada aspek care giver perawat telah melakukannya dari pengkajian hingga adanya evaluasi terhadap tindakan yang telah diberikan kepada pasien, hanya saja 
perawat perlu melakukannya sampai pada masalah psikis karena setiap pasien yang datang ke IGD memiliki sifat unik yang artinya berbeda juga dalam memberikan respon. Setiap pasien ingin ditangani dengan segera, namun pasien maupun keluarga juga tidak semua berasal dari latar belakang kesehatan yangtentu tidak mengerti tingkat kegawatan yang dialami dan prioritas penanganan yang sesuai untuk diperolehnya. Oleh karena itu untuk meminimalkan terjadinya kesenjangan antara pasien/keluarga dengan perawat pada penanganan awal di triage, maka perawat juga perlu memberikan penjelasan hal tersebut terhadap pasien atau keluarga, sehingga pasien/keluarga akan mendapatkan pelayanan yang sesuai dan merasakan puas. Hal ini sesuai gagasan yang disampaikan oleh Kartikawati (2012: 2-3) bahwa pelayanan yang sesuai dengan keluhan pasien akan menentukan tingkat kepuasan pasien. Hal ini dipertegas oleh pendapat Iskandar (2013: 35) yang menyatakan bahwa dalam aspek care giver perawat harus memberikan pelayanan keperawatan kepada individu maupun keluarga dengan tetap memperhatikan kebutuhan yang signifikan dari pasien karena dalam hal ini pasien sebagai makhluk yang holistik dan unik.

Perawat juga telah melakukan aspek client advocate dengan memberikan informasi maupun permintaan persetujuan dari pasien atau keluarga pasien atas tindakan yang akan diberikan. Hal ini sesuai dengan Iskandar (2013: 35) yang menyatakan bahwa perawat bertanggung jawab membantu klien dan keluarga dalam menginterpretasikan informasi dari berbagai pemberi pelayanan dan dalam memberikan informasi lain yang diperlukan untuk mengambil persetujuan (Informed Concent) atas tindakan keperawatan yang diberikan kepadanya. Selain itu, pasien yang berada di Instalasi Gawat Daruratjuga dalam kondisi yang unik artinya pasien dalam berbagai macam tingkatan diantaranyakondisi sadar atau pasien tidak sadar. Hal ini tentu menyulitkan petugas kesehatan dalam memberikan pelayanan yang tepat bagi pasien. Oleh karena itu, perawat juga telah memberikan masukan kepada pasien pada pasien atau keluarga pasien dalam mengambil keputusan terkait tindakan medis yang akan dilakukan. Menurut Lisa Kennedy Sheldon (2009: 27) menjelaskan bahwa perawat menunjukan penghargaan kepada pasien 
dengan membantu pasien atau keluarga dalam pengambilan keputusan, perawat menyampaikan kembali informasi yang mudah dipahami oleh pasien serta perawat dapat membantu memberikan pertimbangan keuntungan dan efek samping dari pilihan yang diambil.

Adapun aspek consellour yang diamatipeneliti meliputi perawat mendengarkan keluhan yang dirasakan pasien atau keluarga pasien, perawat berusaha menemukan masalah yang dihadapi pasien, perawat membantu memberikan alternatif pemecahan masalah pasien dengan fokus pada masalah keperawatan dan perawat memberikan konseling kepada pasien atau keluarga terkait kondisi kesehatan pasien. Kondisi kesehatan seorang pasiensaat ini dapat dipengaruhi oleh berbagai hal salah satunya adanya riwayat kesehatan di masa lalu, sehingga peran consellour sangat diperlukan dalam menggali pengalaman tersebut. Hal ini sejalan dengan gagasan yang disampaikan oleh Lisa Kennedy Sheldon (2009: 67) pasien atau keluarga yang berada dalam lingkup keperawatan tidak hanya memberikan informasi kesehatan pasien kepada salah satu profesi kesehatan lainnya saja, akan tetapi perawat berhak mengakses segala informasi mengenai kesehatan pasien, karena yang berhadapan langsung dengan pasien adalah perawat itu sendiri. Hal tersebut sesuai dengan Iskandar (2013: 35) yang menyatakan perawat memberikan konseling atau bimbingan penyuluhan kepada pasien atau keluargadalam mengintegrasikan pengalaman kesehatan saat ini dengan pengalaman yang lalu.

Pasien maupun keluarga yang datang ke IGD tentu dari latar belakang pendidikan dan pengetahuan yang berbeda-beda dalam hal kesehatan. Hal ini memerlukan adanya suatu informasi yang dapat pasien maupun keluarga peroleh terhadap petugas kesehatan. Perawat merupakan salah satu petugas kesehatan yang paling lama kontak dengan pasien maupun keluarga, sehingga perawat perlu melakukan perannya sebagai pendidik terhadap kebutuhan pasien maupun keluarga akan informasi atas masalah kesehatannya. Hal ini sesuai dengan pendapat Lisa Kennedy Sheldon (2009: 14) yang menyatakan bahwa perawat memiliki peran pengajar yang bertugas sebagai mengajarkan pasien, memberikan intruksi dan pelatihan. Iskandar (2013: 35) juga menyatakan gagasannya bahwa sebagai pendidik pasien, perawat membantu pasien meningkatkan kesehatannya melalui pemberian 
pengetahuan yang terkait dengan keperawatan dan tindakan medik yang diterima sehingga pasien/ keluarga dapat menerima tanggung jawab terhadap hal hal yang diketahui.

Pada aspek collaborator yang diamati peneliti meliputiperawat bekerja sama dengan anggota tim kesehatan lainnya dalam memberikan pelayanan siap tanggap darurat kepada pasien dan perawat juga bekerja sama dengan keluarga dalam membantu pemberian asuhan keperawatan. Hal ini sesuai dengan gagasan Lisa Kennedy Sheldon (2009: 146) menyatakan bahwa perawat tidak hanya bekerja dengan pasien tetapi juga keluarga pasien, sehingga perawat perlu berkomunikasi dengan keluarga, karena hubungan di dalam keluarga mempengaruhi komunikasi dan adaptasi pasien terhadap perubahan kesehatan. Iskandar (2013: 35) juga menyampaikan gagasannya bahwa peran perawat dalam hal inijuga dilakukan karena perawat bekerja melalui tim kesehatan yang terdiri dari dokter, fisioterapis, ahli gizi dan lain-lain dengan berupaya mengidentifikasi pelayanan keperawatan yang diperlukan termasuk diskusi atau tukar pendapat dalam penentuan bentuk pelayanan selanjutnya. Hal ini sejalan dengan pendapat Susanto (2012) dalam
Heru Setyawan (2015) menyatakan bahwa peran perawat sebagai kolaborator yaitu perawat bekerja sama dengan anggota tim kesehatan lainnya dalam memberikan pelayanan kepada klien.Aspek collaborator yang telah dilakukan perawat dengan petugas kesehatan lainnya, dapat berupa diksusi masalah kesehatan pasien, pendelegasian tindakan dari dokter (seperti pemasangan iv line, kateter, dan lain-lain).

Pada aspek coordinator yang diamati peneliti meliputiperawat berkoordinasi dengan petugas kesehatan lainnya dalam menemukan masalah pasien dan perawat berkoordinasi dengan petugas kesehatan lainnya dalam memberikan intervensi yang tepat. Menurut Doheny (1982) dalam Iskandar (2013: 33) menyatakan perawat sebagai koordinator artinya memanfaatkan sumber-sumber dan potensi klien. Hal ini sejalan dengan gagasan yang disampaikan oleh Iskandar (2013: 35) perawat memanfaatkan semua sumber-sumber dan potensi yang ada, baik materi maupun kemampuan klien secara terkoordinasi sehingga tidak ada intervensi yang terlewatkan maupun tumpang tindih.

1. Kepuasan Pelanggan

Berdasarkan hasil penelitian menunjukkan bahwa kepuasan pelanggan di 
Instalasi Gawat Darurat Rumah Sakit Umum Kabupaten Tangerang sebagian besar dalam kategori puas sebanyak 90 responden $(84,9 \%)$. Kepuasan pelanggan tersebutmerupakan penilaian yang diberikan oleh pasien atau keluarga pasien atas jasa pelayanan yang diterima. Hal ini sejalan dengan gagasan yang disampaikan oleh Priyoto (2014: 246) menyatakan bahwa kepuasan pasien adalah perbedaan antara harapan pasien dengan kenyataan yang diterima. Hal ini juga sesuaidengan gagasan Irawan (2002:3). Kepuasan pelanggan adalah hasil akumulasi dari konsumen atau pelanggan dalam menggunakan produk atau jasa.

Jasa tersebut berkaitan dengan kinerja seorang perawat sesuai perannya dalam waktu tanggap (response time)yang selanjutnya akan mempengaruhi penilaian pasien atau keluarga terhadap jasa tersebut. Hal ini sesuai dengan pendapat Sunyoto (2013: 35) menyatakan bahwa kepuasan pelanggan adalah tingkat perasaan seseorang setelah membandingkan (kinerja atau hasil) yang dirasakan dibandingkan dengan harapannya, jadi tingkat kepuasan adalah fungsi dari perbedaan antara kinerja yang dirasakan dengan harapan. Adapun aspek penilaian kepuasan pelanggan dalam penelitian ini meliputi sikap peduli (empati), penampilan fisik (kerapian), kecepatan petugas menanggapai keluhan pasien (responsiveness), keandalan dan keterampilan (reliability) dan jaminan keamanan yang ditunjukkan oleh petugas kesehatan (assurance). Hal tersebut juga sesuai dengan hasil penelitian yang dilakukan oleh Hermawan D. Pisu, dkk (2015) menyatakan bahwa kepuasan pasien berkaitan erat dengan mutu pelayanan keperawatan yang diberikan perawat kepada pasien serta ketepatan dan kecepatan memberikan pelayanan dapat menunjang tingkat kepuasan pasien.

Setiap pasien akan merasakan puas ketika pelayanan yang diterima sesuai dengan harapan, namun pasien akan merasa kecewa ketika pelayanan tidak sesuai dengan harapan, sehingga membuat pasien atau keluarga merasa tidak nyaman dan tidak akan kembali lagi ke fasilitas pelayanan tersebut. Hal tersebut sejalan dengan pendapat Marsudi (2002) dalam Suryati (2012) menyatakan terdapat kecenderungan yang tinggi dari pasien untuk beralih ke tempat pelayanan kesehatan lain bila mereka tidak puas. Oleh karena itu rumah sakit perlu memperhatikan aspek kepuasan pelanggan sebagai dasar dalam menilai mutu pelayanan, karena penilaian satu pelanggan saja dapat memberikan pengaruh besar terhadap citra pelayanan tersebut. Hal ini sesuai dengan gagasan yang disampaikan oleh A.A. Gde Muninjaya (2013: 169) bahwa suatu rumah 
sakit harus berusaha agar jasa pelayanan yang ditawarkan mampu dipertahankan atau tercipta pelanggan baru karena cerita dari mulut ke mulut oleh pengguna jasa sebelumnya.

2. Hubungan antara Peran Perawat dalam

Waktu Tanggap (Response Time) dengan

Tingkat Kepuasan Pelanggan

Berdasarkan hasil uji statistik dengan menggunakan Chi-Square atau Kai Kuadrat pada tabel 2 maka dapat disimpulkan terdapat hubungan signifikan antara peran perawat dalam response time dengan tingkat kepuasan pelanggan di Instalasi Gawat Darurat Rumah Sakit Umum Kabupaten Tangerang, karena nilai p-value pada continuity correction ${ }^{b}$ yaitu sebesar $0,001<0,05$.

Kepuasan yang dirasakan pasien maupun keluarga menunjukkan bahwa perawat telah memberikan pelayanan yang baikdari sisi sikap peduli (empati), penampilan fisik (kerapian), responsiveness (kecepatan petugas menanggapai keluhan pasien), reliability (keandalan dan keterampilan) dan assurance (jaminan keamanan yang ditunjukkan oleh petugas kesehatan). Hal tersebut sejalan dengan penelitian Gobel, dkk (2016) yang berjudul hubungan peran perawat sebagai care giver dengan tingkat kepuasan pasien Instalasi Gawat Darurat di RSU GMIBM Monompia
Kotamobagu Kabupaten Bolaang Mongondow menyatakan bahwa terdapat hubungan antara peran perawat sebagai care giver dengan tingkat kepuasan pasien di Instalasi Gawat Darurat di RSU GMIBM Monompia Kotamobagu Kabupaten Bolaang Mongondow dari hasil p-value pada penelitiannya yaitu 0,000 lebih kecil dibandingkan 0,005.

Hasil penelitian sebelumnya juga telah dilakukan oleh Mustofa (2008) menyatakan bahwa terdapat hubungan antara persepsi pasien terhadap dimensi pelayanan keperawatan dengan kepuasan pasien menggunakan uji Chi-Square dengan nilai $p$-value 0,002 lebih kecil dibandingkan 0,005. Kepuasan pelanggan menjadi hal utama dalam sebuah pelayanan, karena adanya penilaian langsung dari pelanggan tersebut menjadi salah satu indikator mutu pelayanan. Adapun jumlah pelanggan yang puas dalam penelitian ini sebanyak 90 responden $(84,9 \%)$, namun pada penelitian ini menunjukkan masih terdapat pelanggan yang tidak puas sebanyak 16 orang $(15,1 \%)$. Ketidakpuasan pelanggan tersebut terjadi ketika pelayanan yang diterima tidak sesuai dengan harapan pasien maupun keluarga.

$$
\text { Pengumpulan data kepuasan }
$$
pelanggan melalui kusioner menunjukkan bahwa masih terdapat beberapa peran 
perawat yang belum dilakukan secara optimal, sehingga kepuasan pelanggan belum terpenuhi atas pelayanan yang diberikan. Oleh karena itu, perlu adanya peningkatan pelayanan baik dari segi komunikasi perawat mengenai masalah kesehatandan peningkatan pendekatan perawat kepada pasien salah satunya dengan melakukannya proses keperawatan sampai pada masalah psikis, karena setiap pasien yang datang ke IGD memiliki sifat unik yang artinya berbeda juga dalam memberikan respon.Hal ini sesuai gagasan yang disampaikan oleh Kartikawati (2012: 2-3) bahwa pelayanan yang sesuai dengan keluhan pasien akan menentukan tingkat kepuasan pasien. Oleh karena itu, diharapkan perawat dapat meningkatkan pelayanan yang optimal bagi pasien maupun keluarga. Pelayanan yang diberikan perawat sesuai perannya dalam waktu tanggap (response time)bukan hanya sekedar menunaikan kewajibannya sebagai perawat tetapi membuat pasien maupun keluarga dapat terpuaskan secara fisik maupun psikis, karena pada dasarnya pelayanan bagaikan seni, tidak memiliki batasan dalam membuatnya menjadi baik, tetapi kreativitas dan inovasi yang tinggi akan menjadikan pelayanan tersebut baik dan menarik. Hal ini sejalan dengan gagasan yang disampaikan Bustami (2011) bahwa mutu seni pelayanan berhubungan dengan lingkungan, sikap, tingkah laku pemberi pelayanan dalam memberikan pelayanan kesehatan termasuk cara berkomunikasi dengan pasien/ masyarakat.

\section{SIMPULAN}

Berdasarkan hasil penelitian dan pembahasan mengenai hubungan peran perawat dalam waktu tanggap (response time) dengan tingkat kepuasan pelanggan maka dapat disimpulkan bahwa:

1. Peran perawat dalam waktu tanggap (response time) di Instalasi Gawat Darurat Rumah Sakit Umum Kabupaten Tangerang sebagian besar dalam kategori baik yaitu sebanyak 91 (85,8\%), tetapi masih terdapat peran perawat yang kurang yaitu sebanyak $15(14,2)$.

2. Tingkat kepuasan pelanggan terhadap peran perawat dalam waktu tanggap (response time) di Instalasi Gawat Darurat Rumah Sakit Umum Kabupaten Tangerang sebagian besar dalam kategori puas yaitu sebanyak 90 responden $(84,9$ $\%)$, tetapi masih ada pelanggan yang tidak puas sebanyak $16(15,1 \%)$.

3. Terdapat hubungan antara peran perawat dengan tingkat kepuasan pelanggan di Instalasi Gawat Darurat Rumah Sakit Umum Kabupaten Tangerang dibuktikan dengan nilai p-value pada continuity correction $^{b}$ yaitu sebesar $0,001<\alpha$ $(0,05)$ pada taraf signifikan $5 \%$. 


\section{UCAPAN TERIMA KASIH}

Kami ucapkan terima kasih kepada Poltekkes Kemenkes Banten dalam membantu pembiayaan penelitian ini.

\section{DAFTAR RUJUKAN}

Badan Penelitian dan Pengembangan Kesehatan Kemenkes RI. 2013. Riset Kesehatan Dasar RISKESDAS 2013. http://www.depkes.go.id/resources/dow nload/general/Hasil\%20Riskesdas\%202 013.pdf diakses tanggal 08 Juni 2017 pukul 00.50 WIB

Beveridge, Robert, Saint John, New Brunswick, Canada, et. al. Implementation Guidelines for The Canadian Emergency Department Triage \& Acuity Scale (CTAS). http://caep.ca/sites/caep.ca/files/caep/fil es/ctased16.pdf diakses pada tanggal 26 Februari 2017 pukul 15. 30 WIB

Budiman. 2011. Penelitian Kesehatan. Cetakan Kesatu. Bandung: Refika Aditama.

Bustami. 2011. Penjaminan Mutu Pelayanan Kesehatan \& Akseptabilitasnya. Jakarta: Erlangga.

Gobel, M.Gledis Sixten. 2016. Hubungan Peran Perawat Sebagai Care Giver Dengan Tingkat Kepuasan Pasien Instalasi Gawat Darurat Di. RSU. GMIBM Monompia Kotamobagu Kabupaten Bolaang Mongondow. No. 2. https://ejournal.unsrat.ac.id/index.php/jk p/article/viewFile/12881/12471. diakses tanggal 08 Juni 2017 pukul $01.00 \mathrm{WIB}$

Haryatun, Nunuk dan Agus Sudaryanto. Perbedaan Waktu Tanggap Tindakan Keperawatan Pasien Cedera Kepala Kategori I-V Di Instalasi Gawat Darurat RSUD DR. Moewardi. Berita Ilmu Keperawatan, ISSN 1979-2697, Vol. 1. No.2, Juni 2008 69-74 http://publikasiilmiah.ums.ac.id/bitstream/h andle/11617/480/2d.pdf?sequence $=1$ di akses pada tanggal $10-02-2017$ pukul 08.30 WIB.

Hasdianah, dkk. 2015. Buku Ajar Dasar Dasar Riset Keperawatan. Cetakan Kesatu. Yogyakarta: Nuha Medika.

Hidayat, A. A.Alimul. 2007. Metode Penelitian Keperawatan dan Teknik Analisis Data. Jakarta : Salemba Medika.

Irawan.D, Handi. 2002. 10 Prinsip Kepuasan Pelanggan. Jakarta: Gramedia.

Iskandar. 2013. Keperawatan Profesional. Jakarta: In Media

Jeyaratnam, J. 2010. Buku Ajar Praktik Kedokteran Kerja. Jakarta: EGC

Kartikawati.N., Dewi. 2012. Buku Ajar Dasar - Dasar Keperawatan Gawat Darurat. Cetakan Kedua. Jakarta: Salemba Medika.

Kementerian Kesehatan RI. 2015. Standar Pelayanan Keperawatan Gawat Darurat Di Rumah Sakit. http://perpustakaan.depkes.go.id:8180/h andle/1223456789/3583 di akses pada tanggal 07 Februari 2017 pukul 23.00 WIB.

Kepmenkes RI Nomor 856. 2009. Standar IGD Rumah Sakit. Jakarta: Menteri Kesehatan.http://sardjitohospital.co.id/sa rdjitowp/wpcontent/uploads/2015/12/kepmenkes856-thn-2009-standar-IGD.pdf diakses pada tanggal 14 Januari 2017 pukul 03.59 WIB.

Krisanty, Paula, dkk. 2009. Asuhan Keperawatan Gawat Darurat. Cetakan: Pertama. Jakarta: Trans Info Media.

Mubarak, Wahid Iqbal dan Nurul Chayatin. 2009. Ilmu Kesehatan Masyarakat: Teori dan Aplikasi. Jakarta: Salemba Medika.

Mustofa, Akhmad. 2008. Hubungan Antara Persepsi Pasien Terhadap Dimensi Mutu Pelayanan Keperawatan Dengan Kepuasan Pasien Di Ruang Rawat Inap 
Rumah Sakit Umum PKU Muhammadiyah Temanggung. http://jurnal.unimus.ac.id/index.php/FIK $\mathrm{keS} /$ article/view/159 diakses pada tanggal 08 Juni 2017 pukul $12.00 \mathrm{WIB}$

Muninjaya, A. A Gde. 2013. Edisi 3.Manajemen Kesehatan. Jakarta : EGC. Notoatmodjo, Soekidjo. 2012. Metodologi Penelitian Kesehatan. Jakarta : Rineka Cipta.

Nursalam. 2011. Konsep dan Penerapan Metodologi Penelitian Ilmu Keperawatan Pedoman Skripsi, Tesis dan Instrumen Penelitian Keperawatan. Edisi kedua. Jakarta : Salemba Medika.

Pisu, H. D. 2015. Hubungan Response Time Perawat Dengan Kepuasan Pasien Di Instalasi Gawat Darurat RSUP Prof. Dr. R.D. Kandou Manado. Skripsi Mahasiwa Program Studi Ilmu Keperawatan Universitas Sam Ratulangi. Manado. Diakses pada tanggal 01 Maret 2017 pukul 04.34 WIB Priyoto. 2014. Teori Sikap dan Perilaku Dalam Kesehatan Dilengkapi Contoh Kuesioner. Yogyakarta: Nuha Medika.

Pusponegoro,A. 2016. Kegawatdaruratan dan Bencana, Solusi dan Petunjuk Teknis Penanggulangan Medik dan Kesehatan. Cetakan: Kesatu. Jakarta Timur : Rayyana Komunikasindo.

Putri, T. H dan Achmad Fanani. 2010. Etika Profesi Keperawatan. Cetakan: Kesatu. Yogyakarta: Citra Pustaka

Sekar, Ruly Ambar. 2015. Peran Perawat Terhadap Ketepatan Waktu Tanggap Penanganan Kasus Cedera Kepala Di Instalasi Gawat Darurat RSUD Dr. Moewardi Surakarta. http://digilib.stikeskusumahusada.ac.id/f iles/disk1/25/01-gdl-rulyambars-12211-skripsi-s.pdf. diakses pada tanggal 26 Februari 2017 pukul 16.13 WIB.

Setyawan, Heru. 2015. Gambaran Pengetahuan Peran Perawat Dalam Ketepatan Waktu Tanggap Penanganan Kasus Gawat Darurat Di Instalasi Gawat Darurat Rumah Sakit Umum
Daerah Karang Anyar. Surakarta: STIKES Kusuma Husada. http://digilib.stikeskusumahusada.ac.id/f iles/disk1/26/01-gdl-herusetyaw-12711-skripsi-m.pdf. diakses pada tanggal 26 Februari 2017 pukul 16.12 WIB.

Sheldon, Lisa Kennedy. 2004. Communication for Nurses: Talking with Patients. Second edition. Thorofare, NJ: Slack. Terjemahan dr. Stella Tinia. 2009. Komunikasi Untuk Keperawatan Berbicara Dengan Pasien. Edisi: Kedua. Jakarta: Erlangga. Sujarweni,V.Wiratna. 2015. Statistik Untuk Kesehatan. Cetakan: Kesatu. Yogyakarta: Gava Media.

Sunyoto, Danang. 2013. Teori, Kuesioner \& Analisis Data Untuk Pemasaran dan Perilaku Konsumen. Cetakan: Pertama. Yogyakarta: Graha Ilmu.

Supardi, Sudibyo dan Rustika. 2013. Buku Ajar Metodologi Riset Keperawatan. Edisi: Pertama. Jakarta: Trans Info Media.

Tim Bantuan Medis Panacea. 2013. Basic Life Support. Edisi: 13. Jakarta: EGC.

Widodo, Eko. 2015. Hubungan Response Time Perawat Dalam Memberikan Pelayanan Dengan Kepuasan Pelanggan Di IGD Rs. Panti Waluyo Surakarta. (skripsi). Surakarta: STIKES Kusuma Husada http://www.stikeskusumahusada.ac.id/di gilib/files/disk1/22/01-gdlekowidodon1064-1-skripsi.-7.pdf diakses pada tanggal 2 Januari 2017 pukul 18.18 WIB.

Yayasan Ambulans Gawat Darurat 118. 2015. Buku Panduan BT \& CLS. Cetakan Keenam. Edisi: Keenam. Tangerang Selatan: Ambulans Gawat Darurat 118. 